\title{
Penegakan Hukum Keimigrasian Terhadap Penyalahgunaan Visa Izin Tinggal Kunjungan Lewat Batas Waktu (Overstay) Pada Warga Negara Asing
}

\author{
AisyahNurannisa Muhlisa ${ }^{2 *}$, Kholis Roisah² \\ 1Fakultas Hukum, Universitas Islam Riau \\ 2Fakultas Hukum, UniversitasDiponegoro \\ *annisamuhlisa96@gmail.com
}

\begin{abstract}
Immigration is the agency authorized to carry traffic control of people entering and leaving Indonesian territory. Indonesian government to support economic growth seeks through the tourism sector to increase foreign exchange resources. The government gives visa free short visits to foreign internationals who visit. A visa is a permit (approval) for entry, in the form of a stamp and initials affixed by the representative official concerned on the applicant's passport. Foreigners make use of the convenience of a visa-free visit by committing immigration related violations such as visa missapprotiation until the residence permit is expired to carry out activities that do not comply with Indonesian immigration law. This article aims to look at the implementation of law enforcement by immigration to foreigners who misuse visa overstay visits. The results of this study are explaining that law enforcement against foreign nationals who abuse residence permits over the deadline is followed in accordance with Law Number 6 of 2011 concerning Immigration and Presidential Regulation Number 21 of 2016 concerning Visa Free Visit, by overseeing the completion of administrative procedures residence permit for visiting foreigners, and acting administratively to those who violate the residence permit by charging foreigners to pay the burden of expenses, and repatriation to the country of origin.
\end{abstract}

\section{Keywords: Msuse; Visit Visa; Overstay.}

\begin{abstract}
ABSTRAK
Imigrasi merupakan instansi yang berwenang menyelenggarakan pengawasan lalu lintas orang masuk dan keluar dari wilayah Indonesia. Pemerintah Indonesia berupaya mendukung pertumbuhan ekonomi melalui sektor pariwisata guna meningkatkan sumber devisa. Sehingga pemerintah memberikan bebas visa kunjungan singkat kepada warga negara asing. Visa merupakan izin (persetujuan) untuk masuk, berwujud cap dan paraf yang dibubuhkan oleh pejabat perwakilan bersangkutan pada paspor pemohon. Orang asing yang masuk ke Indonesia memanfaatkan kemudahan bebas visa kunjungan dengan melakukan pelanggaran keimigrasian seperti penyalahgunaan batas waktu izin tinggal untuk melaksanakan kegiatan-kegiatan yang tidak sesuai aturan hukum keimigrasian. Penelitian ini bertujuan mengkaji penegakan hukum oleh keimigrasian kepada orang asing yang melakukan penyalahgunaan visa kunjungan lewat batas waktu. Hasil penelitian ini melihat bagaimana penegakan hukum keimigrasian bertindak sesuai Undang-Undang Nomor 6 Tahun 2011 tentang Keimigrasian dan Peraturan Presiden Nomor 21 Tahun 2016 tentang Bebas Visa Kunjungan, dengan cara pengawasan kelengkapan prosedur administratif izin tinggal kunjungan orang asing, dan menindak secara administratif kepada yang melanggar izin tinggal dengan mengenakan kepada orang asing membayar biaya beban, dan pemulangan kenegara asal.
\end{abstract}

Kata Kunci: Penyalahgunaan; Visa Kunjungan; Lewat Batas Waktu. 


\section{A. PENDAHULUAN}

Indonesia merupakan negara berdaulat yang terdiri dari penduduk atau rakyat yang secara umum dapat diartikan sebagai anggota negara. Penduduk (ingezetenen) atau rakyat mempunyai kedudukan yang khusus terhadap negaranya merupakan salah satu unsur untuk memenuhi kriteria dari suatu negara.

Undang-Undang Dasar Negara Republik Indonesia tahun 1945 BAB X tentang Warga Negara dan Penduduk Pasal 26 ayat (1) menyatakan bahwa: "Yang menjadi warga negara ialah orang-orang bangsa Indonesia dan orang-orang bangsa lain yang disahkan dengan undang-undang sebagai warga negara". Menurut Samidjo penduduk yang mendiami suatu Negara ditinjau dari segi hukum terdiri dari warga negara (staatsburgers), dan orang asing yang merupakan selain penduduk asli dalam satu wilayah negara (niet-ingezetenen), orang yang bukan warga negara Indonesia, bukan asli Indonesia, maupun orang Indonesia yang telah melepaskan kewarganegaraannya, dan sedang berada di wilayah Indonesia diberlakukan sebagai orang asing. (Firmansyah, 2013).

Kehadiran orang asing di Indonesia berpengaruh pada peraturan dan kebijakan keimigrasian. Setiap orang dimudahkan untuk melakukan perjalanan, dari suatu negara ke negara lain. Kemajuan teknologi dan sumber daya manusia yang semakin pesat, serta berkembangnya sarana dan prasarana dalam bidang transportasi dan komunikasi meyebabkan semakin meningkatnya arus lalu lintas masyarakat internasional.

Berbagai Negara di dunia berlomba untuk meningkatkan pertumbuhan ekonomi melalui sektor pariwisata guna meningkatan sumber devisa (Sudini, 2008). Keindahan alam Indonesia menjadi daya tarik bagi wisatawan asing untuk berkunjung ke Indonesia, sehingga untuk terus meningkatkan jumlah wisatawan dengan alas an ekonomi dan pariwisata (Bond, \& Chen, 2017), pemerintah mengeluarkan kebijakan dan juga telah diterapkan berupa pemberian Bebas Visa Kunjungan singkat kepada warga negara asing yang dituangkan ke dalam Peraturan Presiden Nomor 21 Tahun 2016 untuk 169 Negara (Prayulianda, Antikowati, 2019).

Menjalin hubungan persahabatan Indonesia dengan negara lain menjadi salah satu gagasan untuk pemberian Bebas Visa Kunjungan didasari dengan alasan-alasan yang sah dan sesuai dengan peraturan yang berlaku seperti: kunjungan singkat transit menuju ke negara lain, kunjungan singkat berwisata, kunjungan karena tugas-tugas pemerintahan, kegiatan sosial budaya, atau usaha maupun untuk tinggal karena urusan pekerjaan, kehadiran orang asing sah apabila melalui jalur-jalur terdaftar seperti pelabuhan, Bandar Udara atau tempat-tempat lain yang ditetapkan oleh menteri kehakiman (Sudini, 2008).

Pemberian izin bebas visa kunjungan memudahkan masuk dan keluarnya orang asing dari wilayah Indonesia, sehingga tidak sedikit dari orang asing menyalahgunakan kesempatan ini. 
Permasalahan penyalahgunaan izin kunjungan dengan kehadirannya di wilayah Indonesia yang dilakukan orang asing menjadi kesempatan yang paling mudah dilakukan oleh orang-orang asing yang tidak bertanggungjawab seperti mencari pekerjaan, menetap untuk mengumpulkan keuntungankeuntungan pribadi, sedangkan Indonesia perlu melindungi hak-hak warga negaranya dalam mendapatkan pekerjaan. Orang asing perlu memenuhi ketentuan-ketentuan dan aturan-aturan untuk dapat berkerja di Indonesia dengan perlu mendaftarkan izin, dan menjadi tenaga kerja yang memang pada bidang tertentu, hal ini menyebabkan negara harus berhati-hati dalam mengambil langkah kebijakan demi keuntungan perekonomian, dan stabilitas keamanan negara serta tidak menyebabkan kerugian hubungan antar negara (Prayulianda, \& Antikowati, 2019).

Imigrasi sebagai instansi yang berwenang dalam menjalankan tugas pemeriksaan imigrasi seperti memberikan persetujuan, izin masuk, ataupun penolakan masuk orang asing ke suatu negara, memberi batasan kedatangan (lama waktu kedatangan orang asing), dan menegaskan kepada orang asing hal-hal apa yang dibolehkan dan tidak (Skrentny, 2012).

Penyalahgunaan visa kunjungan dikategorikan melanggar ketentuan Pasal 38 Undang-Undang Nomor 6 tahun 2011 tentang Keimigrasian dan Peraturan Presiden Nomor 21 Tahun 2016 tentang Bebas Visa Kunjungan (Malfiyanti, Matompo, \& Hasmin, 2018). Peningkatan jumlah pelanggar izin kunjungan oleh orang asing yang berasal dari negara-negara subyek bebas visa perlu kembali menjadi pertimbangan (Ethier,2016).

Perlu adanya ketegasan penegakan hukum keimigrasian untuk orang asing yang tidak mentaati aturan keberadaannya di Indonesia demi mewujudkan kedaulatan dan martabat bangsa (Arifin, 2018). Direktorat Jenderal Imigrasi sebagai pengemban tugas penjaga pintu gerbang negara demi kuatnya kedaulatan dan kesejahteraan negara pada kebijakan bebas visa penegakan hukum keimigrasian berpedoman pada UU no. 6 Tahun 2011 Keimigrasian.

Melihat permasalahan uraian latar belakang dalam penelitian ini dapat dirumuskan pokok-pokok permasalahan yang akan dikaji, yaitu: (1).Meninjau prosedur pemberian izin masuk sesuai ketentuan hukum keimigrasian, (2).Meninjau bentuk pengawasan dan pencegahan penyalahgunaan visa tinggal kunjungan lewat batas waktu, (3).Meninjau penindakan keimigrasian terhadap orang asing penyalahgunaan izin visa kunjungan lewat batas waktu (overstay). Tujuan dari penelitian ini agar orang asing dapat mentaati aturan-aturan hukum keimigrasian yang dilaksanakan instansi keimigrasian secara tegas dalam menerapkan aturan hukum yang berlaku.

Pada penelitian sebelumnya terkait penegakan hukum oleh keimigrasian terhadap orang asing penyalahgunaan visa kunjungan lewat batas waktu (overstay) belum pernah dilakukan. Penelitian oleh Ariani membahas tentang penegakan hukum 
Jurnal Pembangunan Hukum Indonesia

Volume 2, Nomor 2, Tahun 2020
Program Studi Magister Ilmu Hukum

Fakultas Hukum Universitas Diponegoro terhadap tenaga kerja asing illegal di Indonesia (Ariani, 2018). Pada penelitian oleh Alvi Syahrin membahas tentang penegakan hukum terhadap menakar kedaulatan negara dalam perspektif imigrasib berfokus pada mengantisipasi dampak pemberian bebas visa pada kedaulatan negara dalam konsep imigrasi (Syahrin, 2018A). Penelitian yang dilakukan Nabila Belbeid membahas mengenai dampak di terbitkannya Perpres Republik Indonesia No.21 tahun 2016 tentang bebas visa kunjungan terhadap tingkat kriminalitas yang dilakukan oleh orang asing (Belbeid, 2017). Penelitian oleh Bond dan Chen meneliti tentang penegakan mengoptimalisi terhadap perusahaan untuk tidak memperkerjakan orang asingsecara illegal (Bond, \& Chen,2017). Dan pada penelitian Robert Warren membahas tentang upaya yang dilaksanakan United States dengan Department of Homeland Security untuk menekankan pengurangan pertumbuhan populasi overstay pengungsi asing (Warren, 2017). Dibandingkan penelitian penulis disini menunjukkan pembaharuan terkait membahas bagaimana pengawasan dan bentuk mencegah penyalahgunaan visa tinggal kunjungan lewat batas waktu, dan membahas bagaimana prosedur izin visa kunjungan sesuai dengan ketentuan hukum keimigrasian.

\section{B. METODE PENELITIAN}

Pembahasan mengenai penyalahgunaan visa kunjungan lewat batas waktu (overstay) ini menggunakan pendekatan penelitian hukum normative yang bersifat kualitatif. Yang dimaksud dalam penerapan hukum normative yang bersifat kualitatif adalahpenelitian yang menggambarkan, menjelaskan, menganalisis, sertamengembangkan konstruksi hukum kedaulatannegara dalam perspektif imigrasi (Marzuki,2015).

Menurut Lexy J. Moleong metode pengumpulan data pada penelitian ini dengan menganalisis fenomena, mengidentifikasi peraturan, mendeskriptifkan kata-kata daribahan hasilpenelitian (karya ilmiah), dan sumber bahan hukum lainnya yang memiliki relevansi pada pembahasan penelitian yang diangkat (Moleong, 2011).

\section{HASIL DAN PEMBAHASAN}

\section{Prosedur Penggunaan Izin Masuk Pengguna} Bebas Visa KunjunganBagi Warga Negara Asing ke Indonesia Sesuai Ketentuan Hukum

\section{Keimigrasian}

Indonesia memiliki hukum keimigrasian guna mengatur lalu lintas warga negara Indonesia asli dan orang asing yang singgah maupun tinggal dalam waktu tertentu. Hukum keimigrasian sebagai pedoman yang mengatur tata tertib orang-orang yang berlalu lintas di wilayah Indonesia, diterapkannya Peraturan Presiden Nomor 21 Tahun 2016 mengenai Bebas Visa Kunjungan maka kehadiran warga negara asing yang masuk ke Indonesia meningkat, semakin meningkatnya wisatawan asing mendorong Imigrasi memiliki tanggungjawab memastikan orang asing yang masuk adalah orang-orang yang mentaati peraturan yang sah demi menjaga keutuhan negara (Syahrin, 2018A). 
Jurnal Pembangunan Hukum Indonesia

Volume 2, Nomor 2, Tahun 2020
Program Studi Magister Ilmu Hukum

Fakultas Hukum Universitas Diponegoro
Visa kunjungan diberikan kepada orang asing berdasarkan Perpres No. 21 tahun 2016 Tentang Bebas Visa Kunjungan, dengan tetap diawasi oleh Imigrasi. Visa kunjungan tersebut turut berpedoman dengan ketentuan UU No. 6 tahun 2011 pasal 38 izin masuk orang asing pemegang bebas visa kunjungan diberikan dalam rangka kunjungan yang lingkupnya sebagai rohaniawan, tenaga ahli, pekerja, peneliti, pelajar, investor, lanjut usia, dan keluarganya, serta orang asing yang terikat dalam perkawinan secara sah dengan warga negara Indonesia, yang akan melakukan perjalanan bertempat tinggal dalam jangka waktu yang terbatas.

Keimigrasian dalam pelaksanaannya apabila terjadi penyalahgunaan izin administrasi dokumen keberadaannya di wilayah Indonesia (Christmarrathus, Istislam, dan Wijayati, 2014). Sesuai fungsi keimigrasian pada Pasal 1 ayat 3 UU No.6 Tahun 2011 bahwa petugas keimigrasian tidak hanya bertugas memberikan pelayanan masyarakat dalam pembuatan paspor juga izin tinggal tetapi keimigrasian juga harus memastikan orang asing yang masuk ke Indonesia tidak berpotensi melakukan pelanggaran hukum serta pengawasan orang asing yang masuk dan keluar Indonesia.

Penting meningkatkan sarana prasarana pengawasan imigrasi dan menegaskan kelengkapan dokumen dalam metode kedatangan sebagai strategi yang memungkinkan mengurangi kedatangan baru agar hanya kelengkapan administrasi yang di anggap legal (Warren,2017).
Pelaksanaan pemberian izin dari Keimigrasian merupakan kewenangan Menteri Hukum dan Hak Asasi Manusia Republik Indonesia yang didelegasikan kepada Pejabat Imigrasi atau Pejabat Dinas Luar Negeri, dokumen dan izin yang harus dipenuhi oleh orang asing atau warga negara asing yang melakukan kunjungan atau datang ke Indonesia adalah berupa; Paspor sebagai dokumen pertama yang harus dipenuhi oleh orang asing untuk dapat melakukan kunjungan atau datang ke Indonesia adalah berupa paspor adalah past atau izin melewati, yang berasal dari kata passy aitu melewati dan port yaitu pelabuhan atau pintu masuk. Berdasarkan Pasal 8 Undang-Undang No. Tahun 2011 Paspor atau dokumen perjalanan yang sah dan berlaku berfungsi sebagai dokumen perjalanan antar negara, bukti identitas diri, dan bukti kewarganegaraan dari pemegang paspor yang bersangkutan pada saat berada diluar wilayah negaranya (Hamidi, 2015).

Pemberian izin berikutnya dengan pemberian visa, visa menurut (Pasal 1 angka 18 UU No. 6 Tahun 2011) tentang Keimigrasian adalah izin tertulis yang diberikan oleh pejabat yang berwenang pada perwakilan Republik Indonesia atau di tempat lainnya yang ditetapkan oleh Republik Indonesia atau tempat lainnya. Pada kunjungan tersebut terhitung sejak tanggal diberikannya izin masuk di wilayah Negara Republik Indonesia warga negara asing diperbolehkan keberdaannya paling lama 60 (enam puluh) hari. Menurut Khairil Anwar pemberian Izin Tinggal Kunjungan sebagai bukti keberadaan yang sah bagi setiap orang asing diwilayah Indonesia, Izin 
Jurnal Pembangunan Hukum Indonesia

Volume 2, Nomor 2, Tahun 2020
Program Studi Magister Ilmu Hukum

Fakultas Hukum Universitas Diponegoro tinggal kunjungan adalah izin tinggal terbagi dalam beberapa kegiatan seperti kegiatan tugas-tugas pemerintah, kegiatan sosial budaya, pendidikan, bisnis atau usaha, pariwisata, jurnalistik, atau singgah untuk meneruskan perjalanan ke negara lain.

Pejabat Imigrasi berwenang melakukan penolakan orang asing untuk masuk wilayah Indonesia apabila orang asing tersebut: 1)Namanya tercantum dalam daftar penangkalan (namanya di blacklist karena alasan-alasan tertentu); 2)Tidak memiliki dokumen perjalanan yang sah dan masih berlaku/paspor yang digunakan tidak sah; 3)Memiliki dokumen keimigrasian yang palsu; tidak memiliki visa, kecuali yang dibebaskan dari kewajiban memiliki visa; 4)Memberi keterangan yang tidak sebenar-benarnya untuk mendapatkan visa; 5)Menderita penyakit yang membahayakan dan bersifat menular bagi kesehatan umum; 6)Terlibat kejahatan tindak pidana internasional dan; 7)Termasuk dalam daftar pencarian orang atas tindak kejahatan untuk ditangkap dari suatu negara asing; 8)Terlibat dalam kegiatan makar terhadap Pemerintah Republik Indonesia; 9)atau termasuk dalam jaringan praktik atau kegiatan prostitusi, perdagangan orang, dan Penyelundupan Manusia (Citrawan, \&Nadilla, 2019).

Kebijakan terkait prosedur administrasi izin kunjungan masuk guna meningkatkan efektivitas dalam mengatasi arus masuknya orang asing dan melakukan illegal dalam urusan perizinan dan melaksanakan prihal yang diluar dari ketentuan yang telah di persyaratkan, operasional kebijakankebijakan ini menjamin pelaksanaan fungsi dan tanggungjawab.

\section{Pelaksanaan Pengawasan dan Pencegahan Penyalahgunaan Visa Tinggal Kunjungan Overstay Dalam Perspektif Keimigrasian}

Undang-Undang Nomor 6 Tahun 2011 tentang Keimigrasian, keimigrasian dimaksud sebagai garda terdepan dalam rangka menjaga tegaknya kedaulatan, sebagai penyelenggara pengawasan hal ihwal lalu lintas orang masuk dan keluar dari wilayah Indonesia (Jazuli, 2016). Pengawasan merupakan serangkaian usaha bertujuan menjaga suatu proses pekerjaan untuk dapat berjalan sesuai dengan rencana yang ditetapkan. Pengawasan penting artinya bagi pelaksanaan suatu pekerjaan untuk menghindari terjadi penyimpangan baik sebelum maupun setelah pelaksanaan pekerjaan. Pada penyalahgunaan visa tinggal kunjungan yang memiliki kewenangan penuh untuk melakukan pengawasan yaitu Menteri Hukum dan Hak Asasi Manusia yang juga mendelegasikan kepada Keimigrasian pusat, provinsi, kabupaten atau kota (Hamidi, 2015).

Hukum keimigrasian adalah himpunan petunjuk yang mengatur tata tertib orang-orang yang berlalu lintas didalam wilayah Indonesia dan pengawasan terhadap orang-orang asing, dalam hal ini yang menjadi sasaran pengawasan keimigrasian adalah orang asing yang masuk atau keluar dari wilayah hukum Indonesia maka wajib memberikan keterangan kedatangan atau keberangkatan berupa 
Jurnal Pembangunan Hukum Indonesia

Volume 2, Nomor 2, Tahun 2020
Program Studi Magister Ilmu Hukum Fakultas Hukum Universitas Diponegoro identitas diri, dokumen-dokumen izin keimigrasian berupa visa yang secara administrasi akan dilakukan pemeriksaan keabsahannya

(Nugraha,

CakabawaLandra, \& Ranawijaya, 2016).

Pemberlakuan bebas visa menimbulkan tindakan pelanggaran seperti adanya penyeludupan tenaga kerja asing illegal bahkan penyeludupan kejahatan perdagangan manusia masuk ke Indonesia dengan hanya menggunakan visa kunjungan (Setiadi, \& Afrizal, 2019).

Ketentuan penolakan kedatangan orang asing berlaku kepada orang asing pemegang bebas visa kunjungan penting untuk meningkatkan keamanan sehingga hukum disuatu negara perlu memusatkan aturannya pada setiap orang yang masuk ke negaranya (Paasi, 2012). Terkait penolakan diberlakukan kepada orang asing yang melakukan pelanggaran, pelanggaran tersebut bervariasi mulai dari pelanggaran administratif keterlambatan melapor wajib lapor keberadaan yang telah melewati masa berlaku yang telah ditetapkan oleh pihak kantor imigrasi sejak kehadiran orang asing masuk (overstay), penyalahgunaan izin tinggal keimigrasian, izin visa kunjungan, dan tidak dapat menunjukkan paspor ketika petugas melakukan pemeriksaan. Dampak negatif dari kebijakan bebas visa yaitu mudahnya ruang gerak keluar dan masuk orang asing, hal itu dapat saja disalah gunakan dengan dimanfaatkan orang asing yang tidak bertanggungjawab atas kehadirannya datang bertujan untuk mengungsi (Baqi, 2018).
Bebas visa juga berdampak pada kejahatan peredaran narkoba berdasarkan laporan Badan Narkotika Nasional (BNN) disampaikan bahwa sejak diberlakukan kebijakan bebas visa terjadi peningkatan jumlah perdagangan narkotika yang signifikan (Syahrin,2018B), dan peredaran minuman keras, dan menyebabkan keresahan lain berupa terjadinya penyelundupan orang atau tenaga kerja ilegal berupa masuknya buruh-buruh dari negara lain yang melaksanakan kegiatan seperti bekerja secara tidak resmi (Belbeid, 2017).

Beberapa kasus pelanggaran warga negara asing yang terjadi di Indonesia tentu harus menjadi perhatian lebih untuk saat ini. Sistem pengawasan keimigrasian dan pengaturan pemberian bebas visa kunjungan perlu untuk kembali dibenahi, karena akan berdampak pada kesejahteraan dan keamanan nasional. Lembaga keimigrasian sebagai fasilitor kesejahteraan masyarakat dan penjaga kedaulatan negara dirasakan lemah dengan diterapkannya bebas visa karenatidak sesuai denganprinsip yang terkandung dalam kebijakan selektif keimigrasian (Syahrin, 2018A).

Pelanggaran yang kerap kali dilakukan oleh warga negara asing yang berkunjungke Indonesia adalah kunjungan lewat batas waktu (overstay) meskipun warga negara asing yang berkunjung ke wilayah Indonesia memiliki izin hal tersebut tidak terlepas dari limit/ masa waktu keberadaan yang telah ditentukan yaitu 60 (enam puluh) hari terhitung sejak pemberian izin masuk, yang sering terjadi 
Jurnal Pembangunan Hukum Indonesia

Volume 2, Nomor 2, Tahun 2020
Program Studi Magister Ilmu Hukum Fakultas Hukum Universitas Diponegoro adalah orang asing melebihi batas waktu yang telah ditentukan (Setiawati, 2015).

Upaya-upaya yang terus dilakukan keimigrasian dengan menerapkan pola pengawasan keimigrasian terhadap mereka orang asing meliputi empat waktu yang diantaranya adalah pada waktu permohonan visa, masuk atau keluar wilayah Indonesia, pemberian Izin Tinggal; dan berada dan melakukan kegiatan di wilayah Indonesia (Hamidi, 2015). Juga dengan berbagai macam cara untuk melakukan pengawasan yang dilakukan keimigrasian guna mengurangi angka penyalahgunaan visa kunjungan yaitu dengan memanfaatkan penggunaan teknologi sebagai sarana memantau keberadaan orang asing seperti penggunaan aplikasi Pelaporan Orang Asing aplikasi guna memudahkan petugas imigrasi mendapatkan informasi keberadaan orang asing secara real time, walaupun tidak sepenuhnya penggunaan aplikasi berbasis online ini berjalan efektif (Mulyawan, 2017).

Penegakan hukum dalam pengawasan orang asing berawal dari keinginan untuk orang asing turut serta mentaati peraturan-peraturan sebagaimana berlaku guna menghindari pelanggaran seperti penyelundupan narkoba, dan beberapa barang terlarang lainnya dan apabila rangkaian Intergrated Criminal Justice System tersebut dilanggar maka akan ditangani oleh pihak berwajib kepolisian.

Upaya untuk menertibkan orang asing selama berada di Indonesia untuk mematuhi aturan jangka waktu kehadirannya dan keberadaan serta kegiatan orang asing di wilayah Indonesia, dilakukanlah pengawasan oleh Pemerintah melalui Dirjen Imigrasi Kementerian Hukum dan HAM. Pengawasan terhadap orang asing di Indonesia meliputi dua hal yaitu masuk dan keluar orang asing ke dan dari wilayah Indonesia. Pengawasan terhadap orang asing dilaksanakan Pemerintah dalam bentuk dan cara sebagai berikut (Supramono, 2012): 1)Pengumpulan dan pengolahan data diri seperti paspor orang asing untuk masuk atau keluarwilayah Indonesia; 2)Pendaftaran secara rinci sejak kehadiran orang asing yang berada di wilayah Indonesia; 3)Pemerintah melaksanakan pengumpulan, pemantauan, dan pengolahan data dan informasi mengenai kegiatan orang asing selama berada di wilayah Indonesia; 4)Menyusun dan menegaskan larangan masuk bagi nama-nama orang asing yang tidak dikehendaki masuk atau keluar wilayah Indonesia karena alasan-alasan ketertiban dan kedaulatan negara; dan 5)Kegiatan lainnya.

Penegakan hukum di Kantor Imigrasi dilaksanakan dalam bentuk pengawasan dan melakukan tindakan administratif. Pengawasan orang asing dilaksanakan menurut Pasal 66 ayat (2) Undang-Undang Nomor 6 Tahun 2011 tentang Keimigrasian untuk mengawasi kegiatan orang asing yang tinggal di wilayah Indonesia, baik kunjungan, tinggal sementara, maupun menetap. Pengawasan Keimigrasian meliputi: pengawasan paling utama dilaksanakan saat orang asing mengajukan permohonan pembuatan visa di Kedutaan Republik Indonesia diluar negeri. Setelah diberikan permohonannya, pengawasan selanjutnya yaitu 
Jurnal Pembangunan Hukum Indonesia

Volume 2, Nomor 2, Tahun 2020
Program Studi Magister Ilmu Hukum

Fakultas Hukum Universitas Diponegoro berupa memeriksa kelengkapan administrasi seperti paspor dan visa, setiap orang asing wajib memberikan keterangan yang diperlukan mengenai identitas diri dan atau keluarganya, melapor jika terjadi perubahan status sipil (perubahan yang menyangkut perkawinan, perceraian, kematian, kelahiran anak, pindah pekerjaan dan berhenti dari pekerjaan), serta perubahanalamat keberadaannyadi Tempat Pemeriksaan Imigrasi yang ada di Bandar Udara atau aksesmasuk lain sepertipelabuhan (Setiawati, 2015).

Pelanggaran hukum administratif yang dilakukan seperti overstay akan di proses juga dengan tindakan administratif keimigrasian diluar proses peradilan yaitu sanksi administratif yang ditetapkan Pejabat Imigrasi terhadap Orang Asingdi luar proses peradilan. Tindakan Administratif Keimigrasian dapat berupa: pencantuman dalam daftar pencegahan masuk (berada) di wilayah Indonesia atau penangkalan; pembatasan, perubahan, atau pembatalan izin tinggal; larangan untuk berada di satu atau beberapa tempat tertentu di wilayah Indonesia; Keharusan untuk bertempat tinggal disuatu tempat tertentu di Wilayah Indonesia; pengenaan biaya beban; dan/atau deportasi dari wilayah Indonesia (Nugroho, 2016).

Pengawasan yang dilakukan keimigrasian bukan untuk membatasi hak-hak warga negara asing untuk melakukan kegiatan-kegiatan kunjungannya, akan tetapi selektifitas yang dilakukan keimigrasian ini untuk menjaga ketentraman bersama, dan dirasakan manfaatnya bagi orang asing yang masuk, dan rakyat Indonesia tidak menjadi resah terhadap orang asing karena keberadaanya yang sah sehingga tidak melakukan tindakan-tindakan membahayakan keamanan dan ketertiban (Syahrin, 2018A).

Tindakan yang dilakukan pihak Imigrasi terhadap warga negara asing yang melakukan pelanggaran keimigrasian yaitu Tindakan Keimigrasian dan penegakan hukum melalui proses peradilan projustisia. Tindakan keimigrasian secara administratif lebih efektif dan efesien, dalam hal penegakan hukum terhadap perbuatan overstay apabila dilandasi atas asas subsidaritas hukum pidana yakni mengedepankan prinsip ultimum remedium dalam hukum pidana maka penyelesaian secara adminsitratif merupakan kebijakan tepat yang tertuju mengenai sasaran. Tindakan yang apabila orang asing melanggar administratif keimigrasian yaitu dengan mendenda dan mendeportasi hal tersebut sebagai bentuk penindakan tegas yang efektif dan efisien untuk dilakukan (Wirasto, 2016).

\section{Penindakan KeimigrasianTerhadap Orang Asing Penyalahgunaan Visa Tinggal Kunjungan Overstay}

Imigrasi meminimalisasikan penyalahgunaan kehadiran overstay yang dilakukan oleh orang asing, imigrasi yang dalam bidangnya menjalankan kebijakan selektif dalam bentuk pemeriksaan keimigrasian (Arifin, 2018) .

Langkah kebijakan bertujuan untuk tetap menjaga hubungan baik antar negara dengan tidak merugikan perekonomian, dan stabilitas keamanan 
dan dampak negatif lainnya seperti menurut Imam Santoso yaitu berupa kejahatan kemanusiaan, penyuludupan narkotika, penjualan wanita dan anak, prostitusi, dan bentuk kejahatan lainnya (Sanusi, 2016).

Kebijakan keimigrasian khususnya dalam pengurusan pemberian visa dan izin keimigrasian sangat berpengaruh apabila ditingkatkan. Dengan disahkannya Perpres No.21 tahun 2016 tentang Bebas Visa Kunjungan warga negara asing dalam rangka berkunjung. Tetap tidak terlepas dari pedoman UU No. 6 Tahun 2011 tentang Keimigrasian.

Orang asing yang tercantum pada daftar penangkalan, tidak memiliki dokumen perjalanan sah dan berlaku, dokumen imigrasi palsu, tidak memiliki Visa kecuali yang dibebaskan dari kewajiban memiliki Visa, member keterangan yang tidak sesuai untuk meperoleh Visa, menderita penyakit menular yang membahayakan dan berdampak pada kesehatan masyarakat umum, terlibat kejahatan internasional, termasuk daftar pencarian sebagai pelaku pidana untuk ditangkapa dan ditindak secara tegas oleh keimigrasian dengan berpedoman pasal 13 UU No.6 Tahun 2011t entang Keimigrasian tindakan tersebut berupa penolakan untuk dapat masuk kewilayah Indonesia (Prayulianda, dan Antikowati, 2019).

Tahapan penindakan yang dilakukan oleh Imigras berawal dari pengawasan administrasi dan pengawasan lapangan dengan melakukan penyelidikan dengan menerima keterangan dari masyarakat atau instansi pemerintah, mendatangi tempat yang terduga kegiatan orang asing yang overstay.

Tindakan setelah menemukan orang asing yang melakukan penyalahgunaan izin tersebut, keimigrasian berwenang menerapkan tindakan administratif keimigrasian sesuai Bab VII UU No. 6 tahun 2011 tentang Keimigrasian pasal 75 ayat (1) Imigrasi dapat melakukan tindakan secara administratif kepada orang asing yang melanggar ketertiban umum dan dipandang tidak menghormati aturan perundang-undangan.

Tindakan administratif yang dimaksud berupa, akan dicantumkan seseorang warga negara asing yang menyalah gunakan izin tersebut akan dicantum kedalam daftar penangkalan dan pencegahan keberadaanya; pembatasan, dirubah atau dibatalkan izin tinggal keberadaannya; larangan berada di satu atau beberapa tempat di wilayah Indonesia, keharusan di tempatkan disuatu tempat seperti di karantina di Rudenim; pengenaan biaya beban; dan dilaksanakan pendeportasian dari wilayah Indonesia.

Penindakan kebijakan-kebijakan kepada orang asing guna menghindari kemungkinan terjadi ketidak sejahteraan Indonesia dengan tegas menselektif orang asing yang akan masuk. Kebijakan keimigrasian ini juga bertujuan mewujudkan ketertiban umum dan keamanan nasional dan menyangkal perbuatan yang bertentangan dengan peraturan perundang-undangan (Arifin, 2018). 
Jurnal Pembangunan Hukum Indonesia

Volume 2, Nomor 2, Tahun 2020
Program Studi Magister Ilmu Hukum

Fakultas Hukum Universitas Diponegoro

\section{SIMPULAN}

Berdasarkan uraian dalam pembahasan penelitian mengenai penegakan hukum keimigrasian terhadap penyalahgunaan visa izin kunjungan lewat batas waktu (overstay) pada warga negara asing, dapat disimpulkan sebagaiberikut : 1) Meningkatnya jumlah wisatawan sangat dirasakan dalam pertumbuhan ekonomi, juga devisa negara, sehingga tidak jarang negara lain termasuk Indonesia memberi akses mudah dengan pemberian bebas visa kunjungan berdasarkan Perpres No. 21 tahun 2016 kepada negara yang menjalin hubungan diplomatik juga dengan negara sahabat lainnya, 2)Kemudahan akeses keluar dan masuknya orang asing itu tidak sedikit terjadi hal-hal yang meresahkan masyarakat seperti overstay, tidak dapat menunjukkan identitas (paspor) ketika petugas melakukan pemeriksaan, hingga penyalahgunaan izin tinggal keimigrasian. 3)Penyalahgunaan bebas visa kepada orang asing mengaku berkunjung padahalmengungsi, melakukan kejahatan perdagangan manusia, kejahatan peredaran narkoba peredaran minuman keras, penyelundupan orang atau tenaga kerja ilegal berupa masuknya buruh-buruh dari negara lain yang melaksanakan kegiatan seperti bekerja. 4)Penegasan yang dilakukan untuk mencegah penyalah gunaan terus di tegaskan oleh Keimigrasian sebagai penegak kedaulatan negara tindakan tersebut dengan memantau dan memanfaatkan penggunaan teknologi sebagai sarana memantau, mengawasi, keberadaan orang asing dengan berbagai upaya seperti pelaporan langsung ataupun melalui aplikasi pelaporan orang asing, dan menindak sesuai dengan masalah yang dilakukan oleh orang asing apabila tindakan tersebut membahayakan nyawa orang lain maka akan diserahkan kepada pihak berwajib, dan apabila pelanggaran masuk dalam kategori administratif maka akan membayar denda (pengenaan biaya beban), pencegahan masuk atau penangkalan, dan deportasi. Perlunya kesadaran oleh warga negara asing adanya ketentuan berupa prosedur yang telah menjadi ketentuan-ketentuan amanat UU No. 6 tahun 2011 yaitu dokumen perjalanan yang sah, masa perizinan berkunjung karena visa kunjungantetaptidakterlepasdari limit/ masa waktu yang telah ditentukan yaitu 60 (enam puluh) hari terhitung sejak pemberian izin masuk.

\section{DAFTAR PUSTAKA}

\section{BUKU}

Hamidi, J. (2015). Hukum Keimigrasian bagi orang asing di Indonesia. Jakarta: Sinar Rafika.

Marzuki, Peter M. (2015). Penelitian Hukum. Jakarta: Kencana Prenada Media Group.

Moleong, Lexy J. (2011). Metodologi Penelitian Kualitati Edisi Revisi. Bandung: Remaja Rosdakarya.

Supramono, G. (2012). Hukum Orang Asing di Indonesia. Jakarta Timur : Sinar Grafika.

\section{JURNAL}

Ariani, Nevery V. (2016). Penegakan Hukum Terhadap Tenaga Kerja Asing llegal di 
Jurnal Pembangunan Hukum Indonesia

Volume 2, Nomor 2, Tahun 2020
Program Studi Magister IImu Hukum Fakultas Hukum Universitas Diponegoro
Indonesia. Jurnal Penelitian Hukum Dej ure,Vol.18,(No.1),pp.115-126.

Arifin, R. (2018). Penolakan Orang Asing ke Indonesia Melalui Tempat Pemeriksaan Imigrasi Di Bandara Internasional: Sebuah Kedaulatan Absolut. Jurnal Kajian Keimigrasian, Vol.1, (No.1), pp. 151-154.

Baqi, Ahmad M. (2018). Implikasi Kebijakan Bebas Visa terhadap Kejahatan Perdagangan Manusia di Indonesia. J ournal of International Relations, Vol.4, (No.3), pp.79-488.

Belbeid, Nabila U. (2017). Dampak Diterbitkannya Peraturan Presiden Republik Indonesia No 21 Tahun 2016 Tentang Bebas Visa Kunjungan Terhadap Tingkat Kriminalitas yang dilakukan oleh Orang Asing di Provinsi Bali. Jurnal Kertha Semaya, Vol.01,(No.10), pp. 1-15.

Bond, Eric W., \& Chen, Tain-Jy. (2017). The Welfare Effects of I llegal Immigration. J ournal of International Economics, Vol.23, (No.3-4), pp.315-328.

Christmarrathus, Shagita., Istislam., \& Wijayati, Herlin. (2014). Pengawasan Dan Tindakan Kantor Imigrasi Kelas I Malang Terhadap Pelanggaran Izin Tinggal Terbatas (Kitas) Yang Dilakukan Warga Negara Asing(Studi Di Kantor Imigrasi Kelas I Malang). Jumal Hukum Universitas Brawijaya, Tanpa Volume (Agustus),pp.1-19.

Citrawan, Harison., \& Nadilla, Sabrina. (2019). Model Kontrol Keimigrasian dalam Mencegah Tindak
Pidana Teroris me di Indonesia. J urnal Lentera Hukum, Vol.6, (No.1), pp. 69-94.

Ethier, Wilfred J. (2016). Illegal immigration: The Host country Problem. The American Economic Review, Vol.76, (no.1), pp.56-71.

Jazuli, A. (2016). Implementasi Kebiijakan Bebas Visa Dalam Perspektif Keimigrasian. Jurnal IImiah Kebijakan Hukum, Vol.10, (No.3), pp.211-225.

Malfiyanti, Andi Ika., Matompo, Osgar S., \& Hasmin, Yusuf. (2018). Penyalahgunaan Fasilitas Bebas Visa Kunjungan Singkat oleh Warga Negara Asing. Jurnal Kolaboratif Sains, Vol.1,(No.1), pp.1137-1147

Mulyawan, B. (2017). Kendala Implementasi Aplikasi Pelaporan Orang Asing. Jurnal IImiah Kebijakan Hukum, Vol.11, (No.3), pp.287-303. Nugraha, Akbar., CakabawaLandra, Putu Tuni., \& Ranawijaya, Ida Bagus Erwin. (2016). Bentuk Pengawasan Terhadap Penyalahgunaan Visa Kunjungan Oleh Warga Negara Asing di Provinsi Bali (Studi Kasus Di Kantor Imigrasi Kelas I Khusus Ngurah Rai). Jurnal Kertha Semaya,Vol.04, (No.01), pp.1-5.

Nugroho, Chahyo O. (2016). Penegakan Hukum Terhadap Orang Asing di Kantor Imigrasi Kelas I Denpasar dan Kelas I KhususBandara I Gusti Ngurah Rai.jurnal Penelitian Hukum De J ure, Vol.17, (No.2), pp.231-247.

Paasi, Anssi. (2012). Border Studies Reanimated: Going Beyond the Territorial/Relational 
Jurnal Pembangunan Hukum Indonesia

Volume 2, Nomor 2, Tahun 2020
Program Studi Magister IImu Hukum Fakultas Hukum Universitas Diponegoro
Devide. Journal Environment and Planning. Vol.44, pp..2303-2309

Prayulianda, Helga Anton., \& Antikowati. (2019).

Pengawasan Warga Negara Asing Penerima

Bebas Visa Kunjungan dalam Pespektif

Hukum Kewarganegaraan. Jurnal Lentera Hukum, Vol.6, (No.1). pp.141-150.

Sanusi, A. (2016). Penegakan Hukum Terhadap

Tindak Pidana Penyalahgunaan Izin Tinggal

Keimigrasian. Jurnal Fiat J ustisia, Vol.10 (No.2), pp.387-411

Setiadi, Wicipto., \& Afrizal, Rakha Aditya. (2019). Implikasi Kebijakan Bebas Visa Berdasarkan Peraturan Presiden tentang Bebas Visa Kunjungan : Perpsektif Ketenagakerjaan. J urnal IImiah Kebijakan Hukum, Vol.13, (No.3), pp.311-322

Setiawati, D. (2015). Penegakan Hukum Terhadap Warga NegaraAsing (WNA) yang Melanggar Izin Tinggal (Overstay). Jurnal Pandecta, Vol.10, (No.1), pp.14-29.

Skrentny, John D. (2012). Japan the United States, and the Philosophical Bases of Immigration Policy. Journal of Research in Crime and Delinquency, Vol.56, (No.8), pp.995-1007

Syahrin, Muhammad A. (2018A). Menakar Kedaulatan Negara Dalam Perspektif Keimigrasian. Jurnal Penelitian Hukum De J ure, Vol.18, (No.1), pp.43-57.

Syahrin, Muhammad A. (2018B). Refleksi Hukum Implementasi Kebijakan Bebas Visa
Kunjungan Dalam Perspektif Keimigrasian. J urnal Fiat J usticia, Vol,4,(No.2), pp.155-169.

Sudini, Luh P. (2008). Peranan Visa On Arrival (VOA) Bagi Orang Asing yang Datang ke Indonesia. Jurnal Hukum dan Pembangunan, Vol.38, (No.3), pp. 335-352.

Warren, R. (2017). Department of Homeland Security Overestimates Visa Overstays for 2016; Overstay Population GrowthNear Zero During theYear. Journal on Migration and Human Security.Vol.5, (No.4), pp.768-779.

Wirasto, W. (2016). Pelaksanaan Pengawasan Warga Negara Asing di Wilayah Kerja Kantor Imigrasi Kelas II Belawan Berdasarkan UU No.6 Tahun 2011 Tentang Keimigrasian. USU Law J ournal, Vol.4, (No.1), pp.168-185.

\section{ARTIKEL / PAPER}

Firmansyah, M. (2013). Kewarganegaraan Republik Indonesia dan Kehilangan Kewarganegaraan Republik Indonesia Berdasarkan UndangUndang No. 12 Tahun 2006. Artikel Repositori Fakultas Hukum Universitas Sumatera Utara, pp.1-19. 